Dig Surg 1995;12:I-V

\title{
Contents, Vol. 12, 1995
}

No. 1

Hepatocellular Carcinoma

Editors: S.T. Fan, Hong Kong; J. Wong, Hong Kong

Preface

Fan, ST.; Wong, J.

5

Etiology and Pathogenesis of Hepatocellular Carcinoma Tsai, S.-L.; Liaw, Y.-F.

7

Pathological Features and Pathological Prognostic Indicators in Hepatocellular Carcinoma Ng, I.O.L.

16

Imaging of Hepatocellular Carcinoma Ohtomo, K.; Itai, Y.

22

Techniques of Hepatectomy for Hepatocellular Carcinoma Nagasue, N.; Hayashi, T.; Uchida, M. 34

Resection of Hepatocellular Carcinoma Associated with Cirrhosis

Kawasaki, S.; Makuuchi, M.; Miyagawa, S.

40

Hepatocellular Carcinoma: A Western Perspective Que, F.G.; Nagorney, D.M.

45

Peri-Operative Care of Patients with Hepatocellular Carcinoma Undergoing Hepatectomy Fan, ST.; Tsui, S.L.

53

Liver Transplantation for Hepatocellular Carcinoma Rogiers, X.; Knoefel, W.T.; Malagó, M.;

Sterneck, M.; Broelsch, Ch.E.

61

Interventional Radiology for Hepatocellular Carcinoma Ngan, H.

65

Radiation and Chemotherapy for Hepatocellular Cancer Sitzmann, J.V.; Abrams, R.A. 73

Early Detection of Hepatocellular Carcinoma Kang, J.Y.; Guan, R.

79

Author Index 85

Subject Index 86

No. 2

Original Paper

Quality of Life and the Course of Biliary and Gastrointestinal 87 
Symptoms after Laparoscopic and Conventional Cholecys-

tectomy

Plaisier, P.W.; van den Hul, R.L.; Nijs, H.G.T.; den Toom, R.;

Terpstra, O.T.; Bruining, H.A.

Trends in Diagnosis, Management, and Outcome of Common 92 Bile Duct Stones: A

Population-Based Study Kullman, E.; Chu, M; Svanvik, J.; Borch, K.

Adult Choledochal Cysts: Surgical Management and Compli- 98

cations

Toufeeq Khan, T.F.; Sherazi, Z.A.; Haji, S.; Shukri, N.; Ghazali, Z.;

Mumtaz, M.; Baqai, F.U.

Prediction of Intestinal Ischemia in Strangulated Obstruction 102 Kawahira, Y.; Nishida, T.;

Nakao, K.; Hamaji, M.; Fujita, N.

Necrotizing Fasciitis 106

Yagmur, O.; Erkocak, E.U.; Sonmez, H.; Alparslan, A.; Demircan, O.; Dalay, C.

Complications after Endoscopic Resection of Colorectal 111

Polyps: Incidence and Therapy Schmidt, W.-U.; Hesterberg, R.; Müller, F.P.

Recurrent Pilonidal Sinus: Etiology and Treatment 117

Søndenaa, K.; Nesvik, I.; Andersen, E.; Pollard, M.L.; Søreide, J.A.

Case Reports

Congenital Anal Atresia and Rectovaginal Fistula in a

43-Year-Old Woman

ísgör, A.; Demirel, M.; Sezgin, E.

Tension Pneumothorax - Another Presentation of Sponta- 124

neous Rupture of the Esophagus Zamir, G.; Kluger, Y.; Muggia-Sullam, M.

Esophageal Perforation - An Unusual Complication following 126 Nissen Fundoplication for

Esophagitis Viste, A.; Janssen, C.W., Jr.; Svanes, K.

Metallic Clips Are Useful for the Endoscopic Closure of 129

Gastric Perforations after Endoscopic Polypectomy Takii, A.; Okamoto, H.; Suda, T.; Sakai, Y.;

Hatakeyama, K.; Sekine, Y.

Gastric Leiomyosarcoma with a Giant Cystic Component and 132

a High Level of Ferritin

Kato, K; Kusano, M.; Onodera, K; Matsuda, M.; Mito, M.;

Miyokawa, N.; Hodgson, W.J.B.

Hepatocellular Carcinoma Invading the Duodenum: 136

Combined Resection of the Lateral Duodenum and Repair

with a Pedicled Gastric Flap

Moriura, S.; Ikeda, S.; Ikezawa, T.; Naiki, K; Sakai, T.; Yokochi, K.;

Kuroda, M.

Surgical Treatment of Solitary Neurofibroma of the Common 140 Hepatic Duct: A Rare Cause of Obstructive Jaundice Dominioni, L.; Bianchi, M.; Chiappa, A.; Dionigi, R.

A Case Report of Acute Phlegmonous Gastritis after Gastric 144 Operation

Nagami, H.; Tamura, K; Kin, S.; Yano, S.; Seshimo, T.; Sumi, S.; Nio, Y.

No. 3

No. 4

Editorial 
Review Article

Gallstone Disease in Pregnancy: Mere Coincidence or 148

Physiologic Response?

Watemberg, S.; Avrahami, R.; Landau, O.; Kott, I.; Deutsch, A.A.

Original Paper

Thoracic Esophagectomy for Lower Esophageal Cancer through 152

Left Oblique Thoracolaparotomy and Right Posterolateral

Thoracotomy

Гwase, K.; Takao, T.; Takenaka, H.; Kido, T.; Tanaka, Y.; Ono, N.

Surgical Treatment of Patients with Esophageal Achalasia 158

Kitamura, K.; Kuwano, H.; Sumiyoshi, K.; Mori, M.; Sugimachi, K.

Effect of Total Parenteral Nutrition on the Postoperative 164

Outcome in Aged Patients with Gastric Cancer Wu, C.-W.; Meng, H.C.; Mok, K.-T.; Kung, S.-

P.; Lin, S.-H.; Liu, W.-Y.; P'eng, F.-K.

Clinical Evaluation of Terbutaline Sulfate as a Potential Agent 171 for Treating Anastomotic

Leakage after Gastric Operation: Effect of Terbutaline Sulfate on Pancreatic Exocrine Secretion

Nagami, H.; Tamura, K.; Kin, S.; Yano, S.; Seshimo, T.; Sumi, S.; Nio, Y.

Decision-Making in Patients with Gallstones: Development of 176 a Clinical Algorithm Using the Instrument of a Consensus Development Conference

Holzinger, F.; Beger, H.G.; Lorenz, W.; Bockhora, H.; Ohmann, C; Büchler, M.W.

Intussusceptions in Adults: Clinical Course and Associated 184

Lesions

Closset, J.; Widera, I.; Houben, J.J.; Braude, P.; Hollemaert, S.;

Lambilliotte, J.P.

How I Do It

Laparoscopic Appendectomy: A Technical Modification 188

Rosado, R.; Aguilar, J.; Medina, P.; Ramirez, D.; Silic, J.; Flores, B.

Case Reports

Fulminant Pseudomembranous Colitis $\quad 190$

Marchena, J.; Rodriguez-San Roman, J.L.; Redondo, E.; Wagner, A.

Huge Cystic Lipogranuloma Mimicking a Malignant Tumor 195 Ambühl, P.M.; Schweizer, W.; Laeng, H.; Ballmer, P.E.

Cervical Esophageal Duplication Cyst. A Case Report and 199

Review of the Literature Barzilai, M.; Sela, L.

Bilioma after Right Hepatectomy Presenting as Hematoma of 203

the Spleen

Feinendegen, D.L.; Triller, J.; Baer, H.U.

Editorial 207

Review Article

Mechanisms of Biliary Carcinogenesis and Preneoplastic 208

Lesions

Holzinger, F.; Baer, H.U.; Büchler, M.W.

Original Paper

Diagnosis and Surgical Indications for Polypoid Lesions of the 215

Gallbladder

Isozaki, H.; Okajima, K.; Ishibashi, T.; Morita, S.; Takeda, Y.; Hara, H.; 
Akimoto, H.; Niki, M.; Okuda, J.

Bile and Pancreatic Enzyme Exclusion Influence Early 220

Ligation-Induced Acute Pancreatitis in Opossums Samuel, I.; Joehl, R.J.

Diagnosis and Surgical Therapy of Dependent and Peduncu- 228

lated Hepatic Tumours

Baer, H.U.; Holzinger, F.; Dennison, A.R.; Zimmermann, A.

Influence of Cartridge Size on the Morbidity of Esophago- 235

jejunal Anastomosis with EEA Stapling Devices

Fernandez-Fernandez, L.; Tejero, E.; Tieso, A.

Surgery for Gastric Cancer Patients Aged 75 and Over 238

Isozaki, H.; Okajima, K.; Ichinona, T.; Fujii, K.; Nomura, E.; Izumi, N.; Takeda, Y.

Recognition of Internal Openings in Perianal Fistulas: 245

A Comparison of Three Procedures Garcia-Olmo, D.; Usero-Rebollo, S.; Cifuentes-Tebar, J.;

Cascales-Sanchez, P.; Lopez-Fando, J.

How I Do It

Laparoscopic Jejunostomy under Local Anesthesia Facilitated 247 by a New Suture Technique

Chung, R.S.; Chari, V.

Case Reports

Medullary Carcinoma of the Stomach with Lymphocytic 250

Infiltration: A Case Report and Literature Review

Gerst, P.H.; Thakur, N.S.; Levy, J.L.; Gheewala, P.; Yang, Y.; Albu, E.

Preservation of Ampulla of Vater for Severe Corrosive Upper 253

Gastrointestinal Injury

Hwang, T.-L.; Chen, H.-M.; Lee, W.-C; Chen, M.-F.

Cancer of the Papilla of Vater: Preoperative Cryostatic Exami- 256

nation of Endoscopic Biopsies to Reduce Risk and Save Time

and Money

Talamini, G; Bassi, C; Zamboni, G; Falconi, M.; Abbas, H.;

Capelli, P.; Pea, M.; Pederzoli, P.

Treatment of Cystadenoma of the Pancreatic Tail by Distal 259

Pancreatectomy and Subtotal Splenectomy Petroianu, A.

Benign Pneumoperitoneum following Colonoscopy 262

Girishkumar, H.M.; Doganay, K.L.; Gerst, P.H.

IV

Contents

No. 5

No. 6

306

Laparoscopic Colorectal Surgery

Editors: M.W. Büchler, Bern; L. Krähenbühl, Bern

Editorial

Laparoscopic Colon Surgery: Do We Need It?

Büchler, M.W.; Krähenbühl, L.

International Results: 
Laparoscopic Colorectal Surgery in Various Countries

Laparoscopic Colorectal Surgery 271

Petropoulos P.; Kiesler, P.; Chanson, C; Nassiopoulos, K.; Steffen, R.

Laparoscopic Large Bowel Procedures 277

Go, P.M.N.Y.H.

Is Laparoscopic Colonic Resection for Carcinoma Feasible 280

and Safe? A French Collective Experience Fingerhut, A.; Millat, B.; Lointier, P.; Hay, J.-M.

Laparoscopic Management of Colorectal Disease. 284

The United States Experience Franklin, M.E., Jr.

Laparoscopic Colorectal Surgery: Indications and Concept of 288

a Multicenter Study

Köckerling, F.; Schneider, C; Reymond, M.A.; Wittekind, C.

Controversies

Laparoscopic versus Conventional Colon Surgery: 293

What Are the Advantages? Greene, F.L.

Pro Laparoscopic Surgery for Colorectal Cancer 296

Buchmann, P.; Christen, D.

Laparoscopic Resection for Colorectal Cancer: $\quad 302$

A Safe Way to Cure Cancer? Seiler, C.A.

Author Index

307

Editorial Review Article

Diagnosis and Management of Postoperative Intra-Abdominal 308

Complications

Schöffel, U.; Farthmann, E.H.

Original Paper

Hydatid Cysts of the Liver - Surgical Treatment 314

Huguier, M.; Hobeika, J.; Houry, S.

Gangrenous Cholecystitis: Seventeen Years of Experience 318

Landau, O.; Watemberg, S.; Kott, I.; Avrahamy, R.; Reiss, R.

Bacterial Translocation and Endotoxemia in Obstructive 321

Jaundice: The Protective Effect of Lactulose Vagianos, C; Koureleas, S.; Arvaniti, A.; Kirkilesis, J.; Scopa, CD.; Dervenis, C; Stavropoulos, M.

Incidental Cholecystectomy Does Not Increase the Risk of 327

Surgery for Gastrointestinal Malignancy

Watemberg, S.; Avrahami, R.; Landau, O.; Nudelman, I.L.; Reiss, R.

Male and Female Urogenital Dysfunction after Operation for 330

Rectal Carcinoma

Øvrebø, K.K.; Søndenaa, K.; Vaage, S.; Tasdemir, I.; Søreide, J.A.

Adhesion Response to Different Forms of Treating a Perito- 334

neal Lesion: An Experimental Study in Rats

Moreno Egea, A.; Aguayo Albasini, J.L.; Zambudio Carmona, G.;

Parrilla Paricio, P.

Hartmann's Procedure in the Treatment of Acute Colonic 338

Conditions 
Papachristodoulou, A.; Misiakos, E.; Kouraklis, G; Safioleas, M.;

Gogas, J.

Case Reports

Biliary-Digestive Anastomosis to Very Peripheral Bile Ducts: 343

Technique and Results

Baer, H.U.; Maddern, G.J.; Dennison, A.R.; Seiler, C; Blumgart, L.H.

Endoscopic Management of Iatrogenic Biliary Fistulas 348

Läuffer, J.M.; Gilg, M.; Schweizer, W.; Büchler, M.W.

Coexisting Anomalies of the Inferior Pancreaticoduodenal 352

Artery and the Left Gastric Vein. Case Report and Clinical

Considerations

Stimec, B.; Milicevic, M.; Bulajic, M.

Duodenal Bleeding Secondary to a Metastatic Squamous Cell 356 Carcinoma of the Lung Neeman, A.; Delpre, G.; Sulkes, A.

Proceedings 358

Acknowlegdement to the Reviewers 362

Author Index Vol. 12, 1995363

Subject Index Vol. 12, 1995365

$\mathrm{V}$ 